\title{
Biological corrosion and vegetation in the aspect of permanent ruin
}

\author{
Maciej Trochonowicz ${ }^{1}$, Beata Klimek ${ }^{2}$, Daniel Lisiecki ${ }^{3}$ \\ ${ }^{1}$ Department of Conservation of Built Heritage, Faculty of Civil Engineering and Architecture \\ Lublin University of Technology,e-mail: m.trochonowicz@pollub.pl \\ ${ }^{2}$ Department of Conservation of Built Heritage, Faculty of Civil Engineering and Architecture \\ Lublin University of Technology, e-mail: b.klimek@pollub.pl \\ ${ }^{3}$ Faculty of Civil Engineering and Architecture, Lublin University of Technology \\ e-mail:d.lisiecki@pollub.pl
}

\begin{abstract}
The article presents the mechanisms of biodegradation of structures of historical objects intended for exposure in the form of a permanent ruin, and principles of proceeding in removing undesirable vegetation in these objects. Particular attention was paid to issues related to the diversity of damage caused by living organisms. Rules for the removal of algae, lichens, and fungi as well as the operating procedures for removing unwanted higher plants are presented.
\end{abstract}

Keywords: permanent ruin, biodegradation, biofouling, biocorrosion removal, greenery removal.

\section{Introduction}

There are a number of factors responsible for the degradation processes of objects protected in the form of a permanent ruin. In most cases, these processes are caused by atmospheric factors (water, sun, frost, wind, etc.), factors associated with changes in groundwater conditions, changes in the statics of objects or human activity. A separate group are living organisms inhabiting and overgrowing objects.

The group of organisms responsible for the destruction of ruins includes mainly single and perennial green plants, trees and shrubs, house fungi, mold fungi, algae, lichens, mosses, and insects $[3,9]$. In the case of objects left in a form of the permanent ruin, the negative effect of house fungi and insects is of marginal significance. All of the others listed to a lesser or greater extent affect the degradation processes of the ruins.

These organisms are responsible for the phenomenon of biological corrosion, also called thebiodeterioration, understood as various forms of destruction of building elements caused by the action of living organisms, so-called the biological pests. There is a distinction between chemical assimilatory and dissimilatory biological corrosion. The first is the most common form of this process and takes place when the material is degraded because of its nutritional value. The second,the chemical dissimilatory biodeterioration (corrosion) occurs when the microbial metabolites damage the material [13].

In the case of masonry, the chemical assimilatory corrosion is of little importance due to the minimal amount of nutrients in the facility. It is limited only to those walls in which wooden elements were used in the structure or wood was used as a material for roofing elements, communication, e.g, bridges and viewpoints on the crown of the walls. 
The phenomenon of dissimilatory biological corrosion is of great importance. The fouling of the surface of materials by living organisms, known in the literature as „,biofouling” can cause a number of adverse changes inside and on the wall surface, corrosion, pigmentation, secretion of toxic metabolites to the material, and damage to the masonry structure due to root system growth [8].

The development of biological corrosion and vegetation causes a number of adverse changes in the ruin. These changes can be divided into: technical, aesthetic, and hygienicsanitary. Technical effects mainly consist in lowering the strength of elements and structures, which leads to their slow degradation. The biological corrosion also has aesthetic significance, it consist in lowering the aesthetic values of the elements infected. The hygienicsanitary effects, consisting in the deterioration of the degree of health of objects for people and animals, in the case of walls in ruin are not significant [12].

From the conservation point of view, the technical effects caused by biological corrosion and vegetation development are by far the most important for the ruins. Therefore, due to the technical nature of the study, in the next part, the greatest emphasis will be placed on the impact of biological corrosion on the degradation processes of ruins, and on the principles of handling the removal of organisms that cause biological corrosion and undesirable vegetation.

\section{Description of destruction mechanisms}

the mechanism of biodegradation of objects protected in the form of ruins is complex and depends on many factors. The most important are: the material from which it was erected, the construction height and thickness of the walls, a moisture status of the walls, the place where it was erected, the type and size of trees in the immediate vicinity, types of organisms inhabiting the walls, quality of care of the manager, etc. All these factors have a smaller or greater impact on the technical condition of the walls associated with the adverse effects of organisms that cause biological corrosion and the presence of undesirable vegetation.

Due to the large variety of damage caused by living organisms, they were proposed to be divided into three groups. The division takes into account the depth of damage and assigns them groups of organisms responsible for destruction.

- Group I - surface damage/algae, bryophytes, mold fungi, and lichens/

- Group II -damage to the depths and crowns/low vegetation - grass, perennials, and succulents/

- Group III -damage to the structure/high vegetation - trees and shrubs/

\subsection{Group I - surface damage}

The first group includes damage caused by the development of organisms devoided of root systems or those in which they have a residual form. This group includes algae, lichens, bryophytes, and mold fungi. These organisms usually only cover the surface of the material. Due to different environmental requirements (humidity, $\mathrm{pH}$ of a substrate, sun exposure) they can develop in various places and on most materials found in objects.

Algae, bryophytes, and mold fungi have quite high requirements for the moisture of the ground, which is why they grow over the basement strip of the walls and shady places. The largest concentrations of these organisms are observed on the walls from the north. Their habitat is usually natural stones and brick, but they also occur on joints and plasters. Initially, 
slow expansion is becoming more and more intense. It is affected by the ability to retain moisture by algae and bryophytes, which leads to even greater moisture content in the substrate. As a consequence, further organisms develop on moist surfaces. Development usually ceases when the humidity conditions change.

Lichens have much lower requirements for a substrate moisture. They are quite resistant to low and high temperatures. Thanks to the possibility of absorbing moisture from the air, they are independent of the ground conditions. They grow stones, bricks, joints, and plasters. Their colors vary widely from bright ones to black. Due to the color of fruiting bodies, they are often treated as a dirt.

The surface damage made by some species of lichens are caused by the secretion of acids and the growth of cells in the pores of the stone. Algae and fungi also secrete organic acids, especially the oxalic acid. Additionally, due to the growth of the fungal hyphae into the pores of materials, their cohesion may be loosened, thus the surface layer is destroyed. In turn, the sulfur bacteria in the metabolic process cause the formation of the sulfuric acid and initiate a series of chemical reactions resulting in cracking and crumbling of materials. The nitrifying bacteria oxidize the ammonia (contained in rainwater, dust, and soot) to the nitric acid, which, e.g., dissolves surface layers of stones creating characteristic stains and craters or so-called the snow blooms [5].

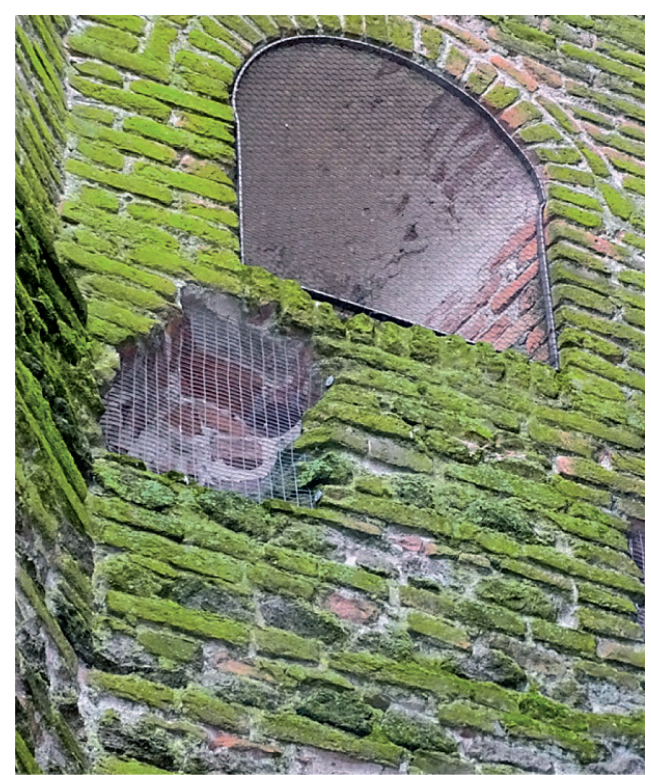

Fig. 1. Algae colonies on a moist ceramic brick wall

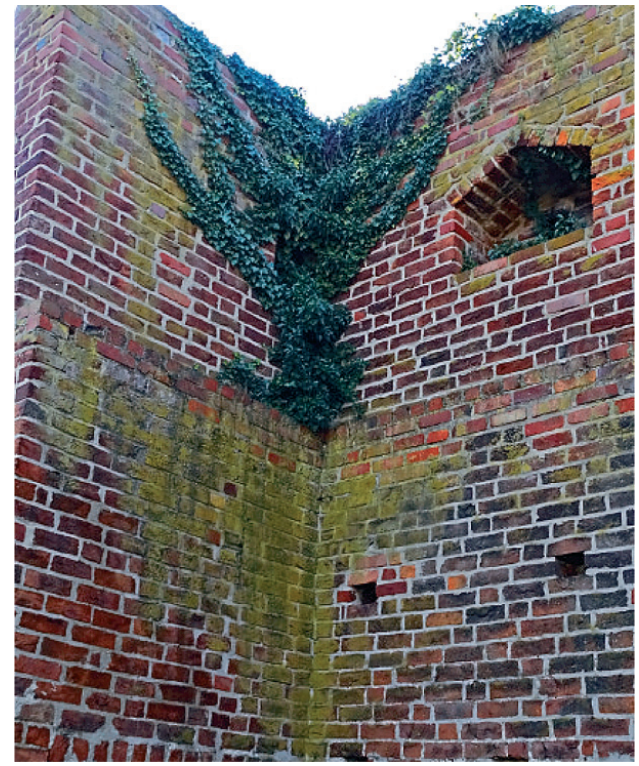

Fig. 2. The development of algae and lichen in the corner of the wall directly under the ivy, which is growing the wall and the crown 


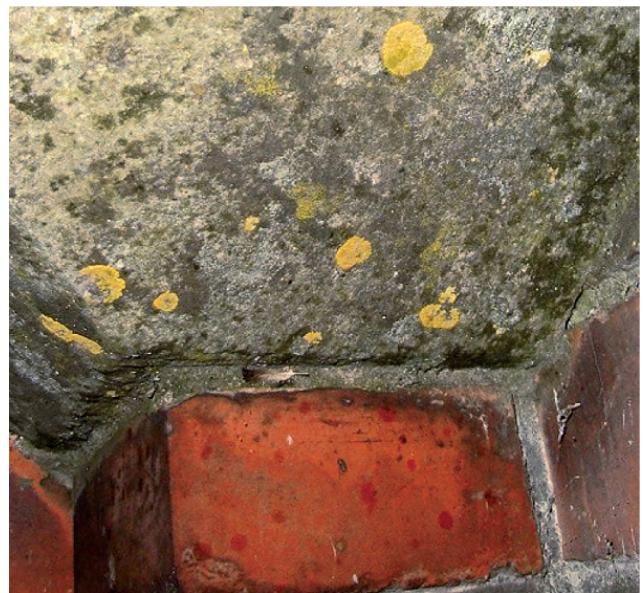

Fig. 3. A fragment of the plastered ceiling overgrown with lichens

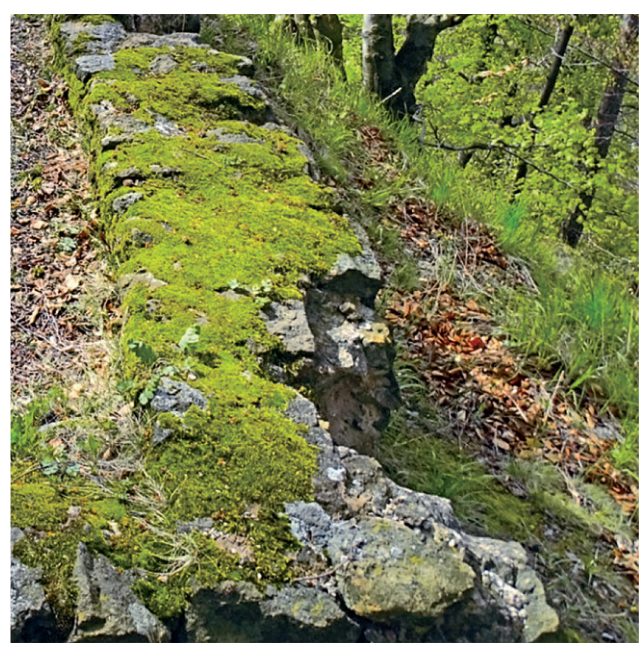

Fig. 5. Mosses growing on the low crown of the north wall of the ruin

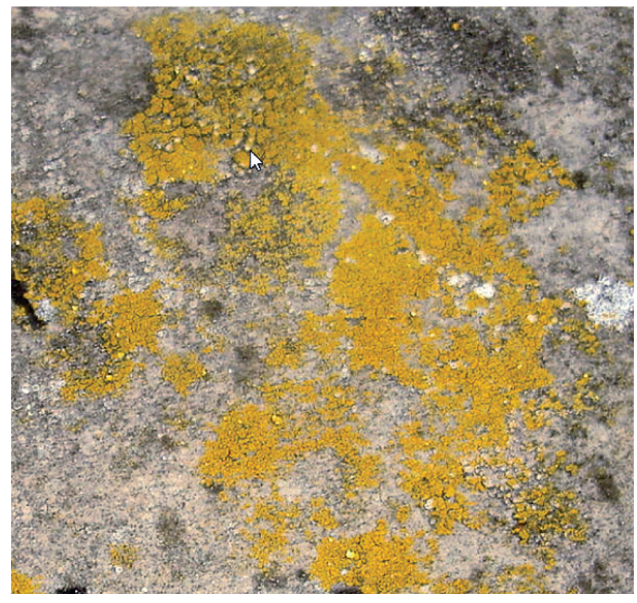

Fig. 4. Colonies of lichens on the historical plaster of the external wall of the object

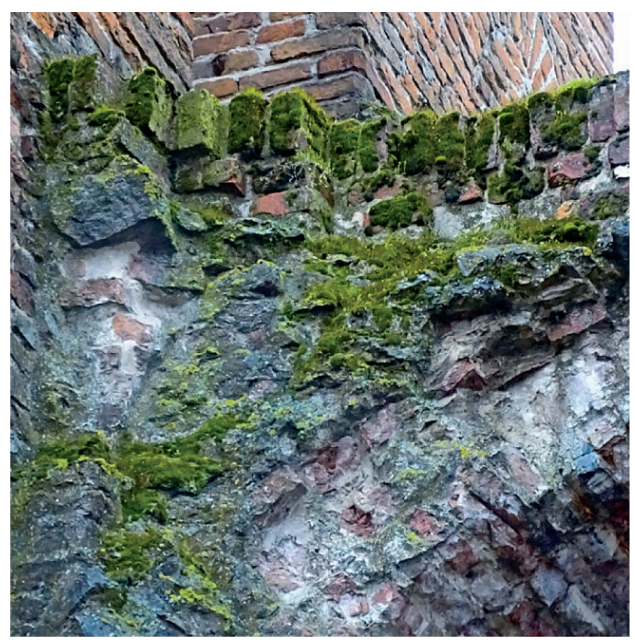

Fig. 6. Moss and algae, which overgrow the crown and the face of the wall

\subsection{Group II - damage to the depths and crowns}

The second group includes deep damage to the surface layers of the wall /face and crown/. Destruction is caused by small plants developing a root system, and consequently requiring a suitable substrate or a place where they can grow. This group includes all species of low vegetation in buildings in ruins: grass, perennials, ivy, and succulents.

The development of green plants begins with the appearance of the minimum amount of humus in the crevices and on the crown of the wall. Initially, mainly small annual plants and grass dominate. Over time, perennial plants appear along with the growth of the humus layer (plant decomposition, wind blowing). Their growth is particularly intense in places where elevated humidity persists, however many species are able to settle dry and sunlit fragments. 
The growth and decay of vegetation causes the appearance of the humic acids in the wall and an increase in the amount of nitrates. Acids cause dissolution of binders in the joints, weakening them and, consequently, a number of damage to the face of the wall. The increase in nitrate concentration is responsible for further damage to the surface layers. Crystallizing salts increase their volume and break the pores of welds and masonry materials. The crystallization pressure is so high that damage occurs even in the case of rocks with high hardness.

Another consequence of the development of low vegetation is damage at the interface between the weld and masonry related to the development of the root system. The expanding roots cause damage to weak /mostly lime or clay/ joints, which can lead to further damage to the face layers /individual detachments of small stones or entire fragments.

Chemical substances released by vegetation and derived from their decomposition also affect the discoloration of the face surface causing negative aesthetic effects.

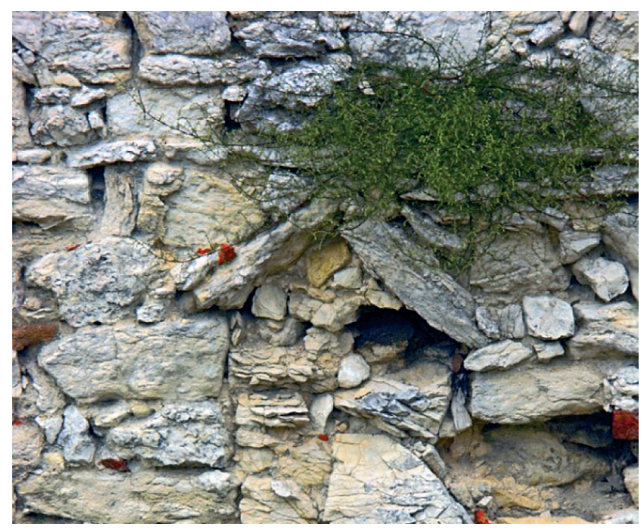

Fig. 7. Photograph of a heavily sunlit southern façade. The development of vegetation in the wall crevices

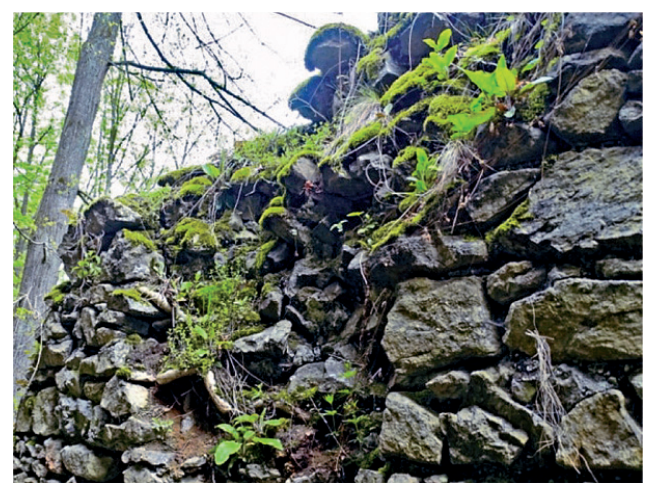

Fig. 9. The crown and the face of the curtain wall planted with a single and perennial vegetation

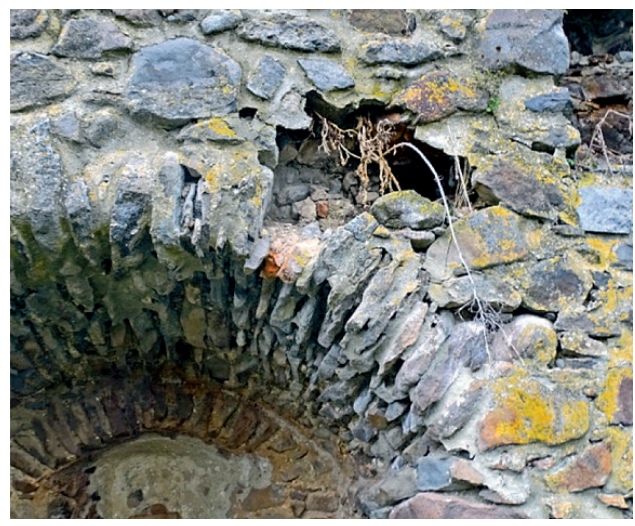

Fig. 8. Damage to the face of the wall associated with the growth of the root system of low vegetation

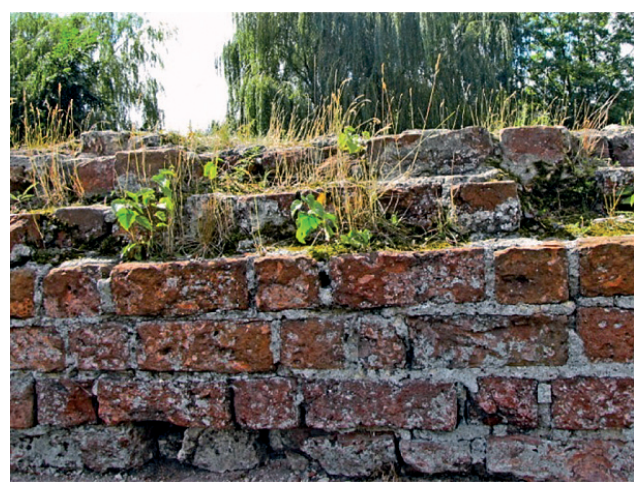

Fig. 10. The expansion of low plants and mosses on the crown of the ceramic brick wall. In the foreground young shrubs are visible 


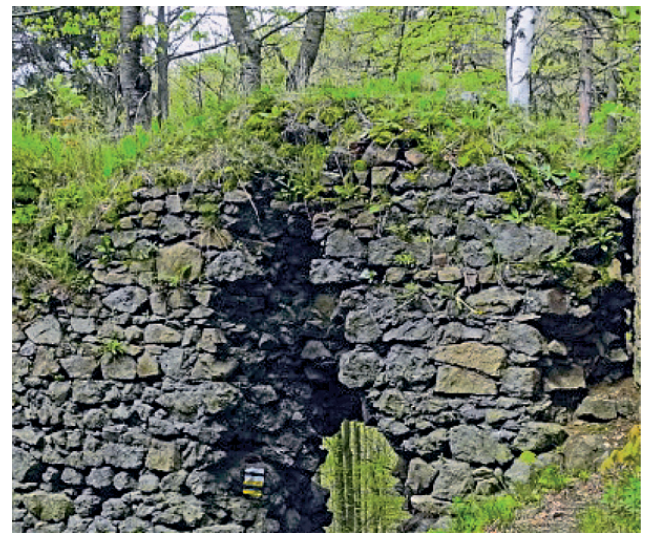

Fig. 11. The low crown of the wall completely overgrown with greenery. The tight layer of humus and greenery prevents evaporation of the moisture retained in the wall

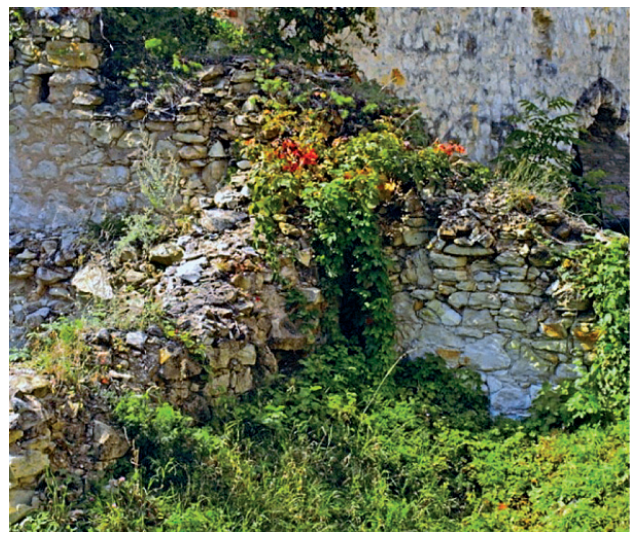

Fig. 12. A wall relic covered with vegetation. A large amount of green causes the illegibility of the ruin

\subsection{Group III - damage to the structure}

The third group includes the large-area damage to the face and wall construction itself. They are caused by perennial plants, which the root system is very extensive and surpasses the walls or vaults of the object. The third group includes trees and shrubs.

The impact of high vegetation on the walls is much greater than in the other groups of organisms described in previous subsections. The roots secrete large amounts of organic acids that cause the decomposition of calcium carbonate in the joints of the masonry walls. This leads to a weakening of the joint-masonry bonds inside the wall. Together with water, these compounds move to the surface, and then after evaporation of water, they crystallize. The crystallization causes sealing of near-surface layers and appearance of carbonate stains.

Falling leaves are found in the crevices and hollows of the wall, and after decomposition they form the basis for the development of low vegetation and bryophytes. In addition, along with water, large amounts of nitrates from the decomposition of leaves enter the wall.

Trees and shrubs also affect the ruin mechanically. The growing roots fill the walls' gaps and cause the emergence of new cracks and surface spalling of stone and brick. Large root systems overwhelming the walls over time can lead to large surface loosening and significant damage to the construction of the entire wall.

The presence of tall trees overgrowing walls or in their immediate surroundings can also be very dangerous during intense storms or strong winds. The tree torn from the roots or broken can lead to significant damage to the ruins or be a threat to the people staying in the facility.

Constant shading of the wall by high vegetation hinders its drying out, which can lead to intensive development of low vegetation, algae, and bryophytes. 


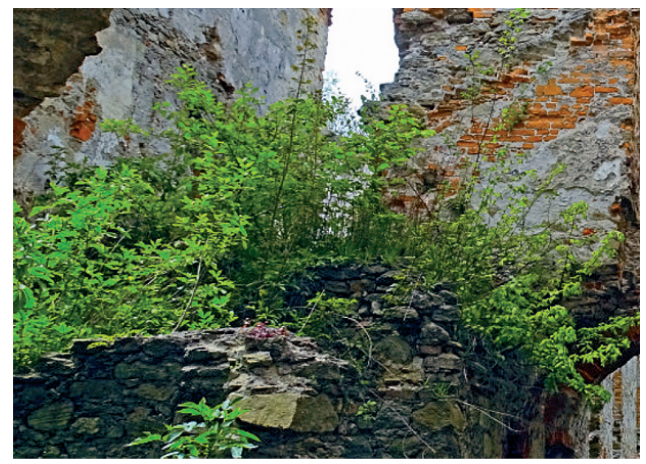

Fig. 13. A fragment of the vault intensely overgrown with shrubs

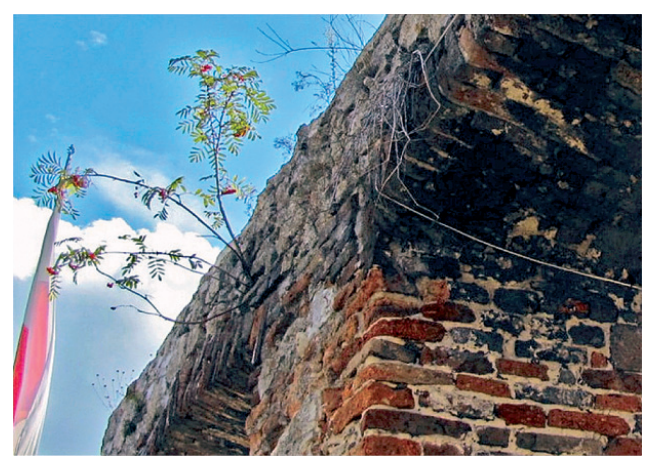

Fig. 15. The rowan rooted in the gap between the wall of the crown and the lintel

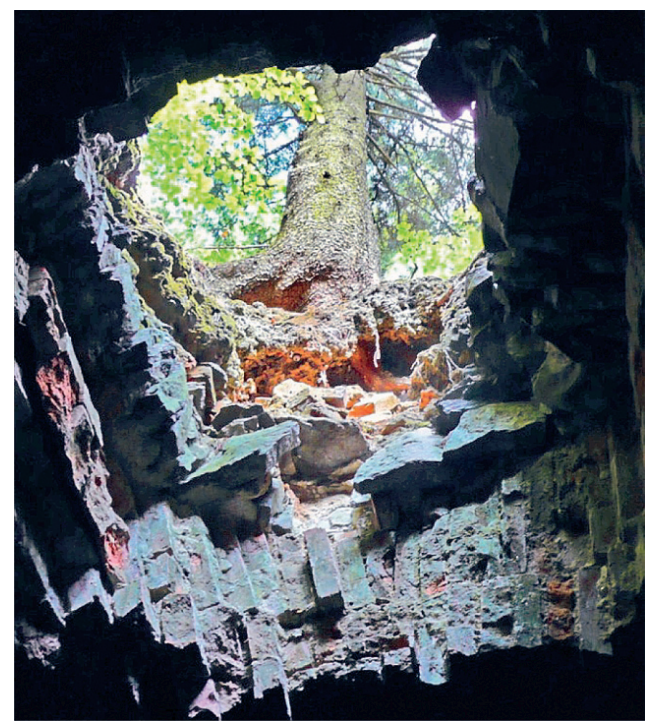

Fig. 17. Vault made of ceramic brick damaged by roots

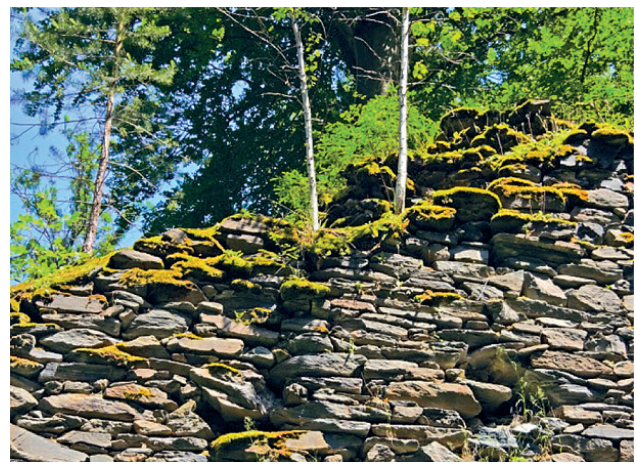

Fig. 14. Stone wall with young birches on the crown

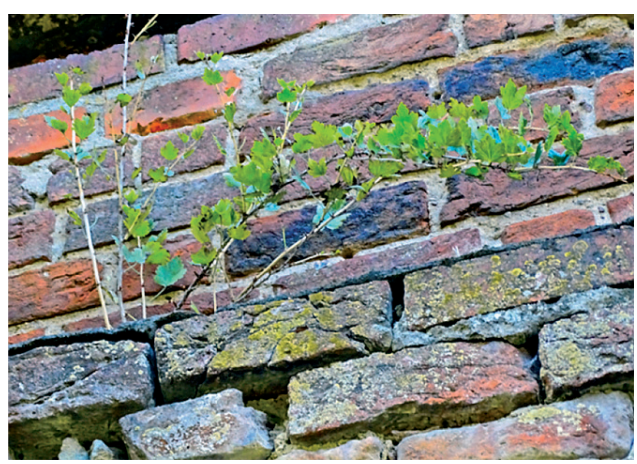

Fig. 16. A shrub with a root system overgrowing a ceramic brick wall

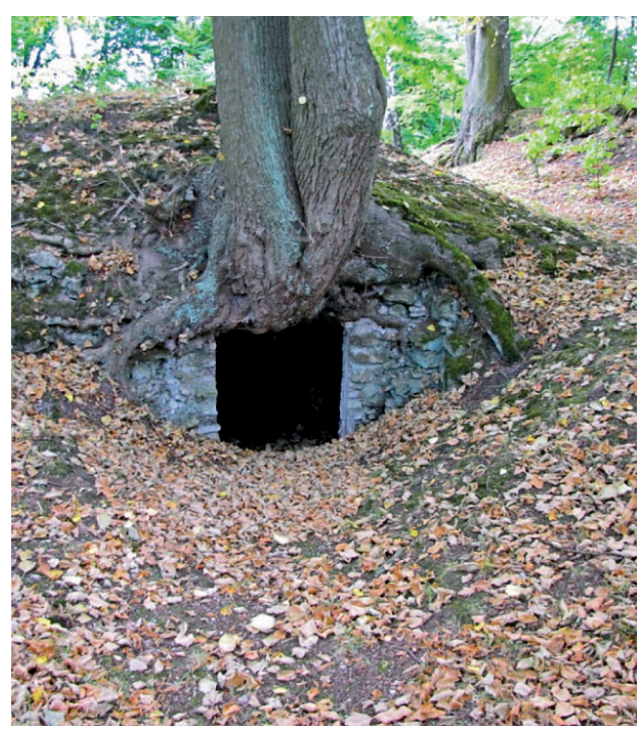

Fig. 18. A huge tree and its root system, which overgrown a stone vault 


\section{Principles of procedure during removing biological corrosion and vegetation}

Problems concerning the impact of vegetation on objects in permanent ruin is an open issue, which is dealt with by architects, conservators, and engineers. In a large number of scientific and popular science publications, a separate group consists of guides for managers and guardians of objects $[2,3,4,9]$. Guidelines indicate the need to consult with specialists before starting any activities related to the treatment of vegetation growing on objects in the permanent ruin.

The removal of organisms responsible for the development of biological corrosion is associated with the need to conduct activities that directly or indirectly can affect the behavior of the ruin itself. Due to the possibility of adverse changes during this work: structural damage, surface damage to the face, damage to the details, change of color, etc., removal of organisms responsible for corrosion should be subjected to specific rules. Due to differences related to the structure of organisms (lack or existence of root systems), the place of occurrence and the type of damage caused by the action of organisms, the rules of conduct were collected in two groups.

\section{Rules for the removal of algae, lichen, mosses, and mold fungi}

- Determinationwhetherexistingorganismsmust be removedorwhethertheirimpact on the materialisnegligible and theycanremain.

- Determination the degree of damage and itstype.

- Adoption a method of organismsremoving. The methodmusttakeintoaccount the surface, the availability, the texture of the material, the strength of the subsurfacelayers, and the degree of damage.

- For mechanicalremoval, itisnecessary to carry out tests of cleaningefficiency and the impact of the methodused on the substrate.

- The use of chemicalpreparationsthatcombatorganismsrequiresdetermining the effect of the substance on the treatedsurfaces. The compoundscontained in the substancesusedmust not causechanges in the structure, reducestrengthorcausechanges in the colorscheme.

- Aftercleaningworks, the wallsurfaceshould be disinfected.

- Determination of the timeafterwhich the treatmentsneed to be repeated.

\section{Rules for handling unwanted vegetation}

- Before starting the work, review the condition of the walls and determination the places where the work will be carried out should be performed.

- Determination which plant groups are to be removed, in certain cases a decision may be made to leave some plants or their parts (ivy, grass growing on protected wall crowns).

- In the case of the need for work at high altitudes, especially when cutting out trees, works should be outsourced to specialists.

- Annual and perennial plants (grasses, perennials, and weeds) should be removed as much as possible with the whole root system.

- After removing the plants from gaps and depressions, the layers of soil that are located there should be also removed, if possible. This treatment will delay the growth of other organisms in the future.

- Before using chemical preparations, each time it is necessary to determine their impact on the material of the ruin. 
- The chemicals used within the ruins must not adversely affect planned vegetation.

- Removal of tall trees both near the walls as well as those with a root system overgrowing the structure must be supported by the analysis of the impact of the cut on the behavior of the walls.

- It is not recommended to remove trunks and roots after tree felling, if they affect the stability of slopes near the walls and the stability of the walls themselves.

- In the case of removal of trees and shrubs, it is necessary to take into account breeding periods of birds.

- After carrying out the cleaning work on the ruin of undesirable greenery, it is recommended to periodically monitor the walls and carry out works preventing fouling.

\section{Summary}

The development of organisms on the walls of objects protected in the form of the permanent ruin is an unavoidable process. The specificity of these buildings /objects that are not roofed, unheated, and often unused and unprotected/ causes that under favorable conditions that prevail there, the organisms will develop all the time. It is important that this development is not uncontrolled. Depriving the walls of care for only a few years can lead to a series of destructions, often of an irreversible nature.

Therefore, it is crucial that such objects should be subjected to periodic inspections, allowing to carry out cleaning works at the moment when corrosion or vegetation growth occurs. Properly conducted inspection allows to decide which species and specimens should be immediately removed, and which left and treated as an element of arrangement. Cyclical activities will not allow excessive growth of vegetation and reduce the costs of activities related to the removal of vegetation.

\section{References}

[1] Building Research Establishment. Control of lichens, moulds and similar growths. Garston, Watford: Building Research Establishment, 1992.

[2] Donnelly J. Ruins: the Conservation and Repair of Masonry Ruins, Government Publications Sales Office, Dublin, 2010.

[3] Eklund J.A., Young M.E. Biological Growth on Masonry: Identification \&Understanding. Inform. Information of historic building owners. Published by Historic Scotland, January 2013.

[4] Fawcett R. Treatment of vegetation at monuments [in:] The Conservation of Architectural Ancient Monuments in Scotland. Guidance on Principles. Published by Historic Scotland. Longmore House. Salisbury Place. Edinburgh 2001, s. 44-47.

[5] Ferraby S. The ecology of ruin sites [in:] Conservation of Ruins, ed. John Ashurst, Elsevier Science \& Technology, 2006, s. 209-210.

[6] Further Reading and Contacts Biological Growths on Sandstone Buildings: Control \& Treatment, Technical, Advice \& Guidance, Technical Advice Notes, Historic Scotland, tom 10, 1997.

[7] Gordon R. University. Biological Growths, Biocide Treatment, Soiling and Decay of Sandstone Buildings and Monuments in Scotland. Report on research commissioned. Historic Scotland and The Robert Gordon University, 1995.

[8] Jasieńko J., Mierzejewska O., Hamrol K., Misztal W. Utrwalanie koron murów obiektów historycznych przeznaczonych do ekspozycji w formie trwatej ruiny, Wiadomości konserwatorskie 30 (2011) 117-132 
[9] Kozarski P., Molski P. Zagospodarowanie i konserwacja zabytkowych budowli. TowarzystwoPrzyjaciół Fortyfikacji, Fortyfikacje tom XIV, Warszawa 2001.

[10] Praca zbiorowa pod redakcją Ważnego J., Karysia J. Ochrona budynków przed korozją biologiczną Arkady, Warszawa 2001.

[11] Quinlan M., Hanna M., Kelly D. The conservation and repair of masonry ruins, - Government of Ireland, Dublin, 2010.

[12] Sieniawska-Kuras A., Potocki P. Przyczyny zniszczeń obiektów budowlanych i elementów architektonicznych. Procesy biologiczne. [w:] Renowacja elementów architektury. Wydawnictwo i handel książkami „KaBe”, Krosno 2012, s. 53-55.

[13] Strzelczyk A.B. Czynniki niszczące kamienie. Czynniki biologiczne [w:] Zabytki kamienne i metalowe ich niszczenie i konserwacja profilaktyczna, red. WiesławDomasłowski. WydawnictwoNaukowe UMK, Toruń 2011, s. 135-157.

[14] Tajchman J. Metoda zabezpieczania i rewitalizacji ruin historycznych jako szczególny rodzaj konserwacji i restauracji zabytków architektury, Materiały z międzynarodowej konferencji naukowej, Gubin 2008.

[15] Trochonowicz M. Zamek w Janowcu nad Wista. Ocena stanu wilgotnościowego i zasolenia murów. Politechnika Lubelska, Lublin 2006.

[16] Young M., Wakefield R. Research commission investigating biological growths, biocide treatment soiling and decay of sandstone buildings and monuments in Scotland. 1995. 